\author{
Miriam Mayburd \\ (iD) https://orcid.org/0000-0002-2194-8365 \\ University of Iceland
}

\title{
Objects and Agency in the Medieval North: The Case of Old Norse Magic Swords
}

\section{Introduction}

Recent decades have seen a resurgence of interest among historians and archaeologists in reassessing trade networks and cross-cultural exchanges between medieval Scandinavia and circum-Baltic regions, particularly the West Slavic area of what is today the territory of Poland. The emergence of new archaeological findings from viking-age Polish sites such as Wolin reveals vibrant ecosystems of long-term Norse settlements, flourishing trade outposts, and workshops locally producing artefacts in Scandinavian styles, demonstrating Norse presence and culture in those areas to have been more complex and multidimensional than heretofore thought. ${ }^{1}$ The comparative recency of

${ }^{1}$ Such as recent studies by W. Duczko: Scandinavians in the Southern Baltic between the $5^{\text {th }}$ and the $10^{\text {th }}$ Centuries AD. In: Origins of Central Europe. Ed. P. UrbańCZYK. Warszawa 1997; W. Duczko: Obecność skandynawska na Pomorzu i stowiańska w Skandynawii we wczesnym średniowieczu. In: Salsa Cholbergiensis. Kolobrzeg w średniowieczu. Eds. L. Leciejewicz, M. Ręвкowski. Kołobrzeg 2000; W. Duczko: Viking Rus. Studies on the Presence of Scandinavians in Eastern Europe. Leiden-Boston 2004; W. Duczko: Viking-Age Wolin (Wollin) in the Norse Context of the Southern Coast of the Baltic Sea. "Scripta Islandica" 2014, Vol. 65; J. Morawiec: Vikings among the Slavs. Jomsborg and the Jomsvikings in Old Norse Tradition. "Studia Medievalia Septentrionalia" 2009, Vol. 17; J. MorawieC: Wolin w średniowiecznej tradycji skandynawskiej. Kraków 2010; B. StanisŁawski, W. Filipowiak: Wolin wczesnośredniowieczny. Część I. Warszawa 2013. Władysław Duczko notes that in eastern Europe "many settlements can be easily recognized as Scandinavian because of family 
this data has led its implications to still be largely neglected in Scandinavian studies, which bear the tendency to regard viking expansion to new territories as infiltration or superimposition of one identity group over another, perpetuating the view of a discrete monolithic culture. Addressing these issues has prompted several international conferences over the past several years dedicated to integrating historical resources from the Eastern frontier into broader Norse studies, ${ }^{2}$ with pronounced efforts to steer both academic discourse and public perception of Norse-Polish matters away from nationalist interpretations that were prevalent in the $19^{\text {th }}$ century and early decades of the $20^{\text {th }}$ century. ${ }^{3}$

Newly emerging archaeological data from excavations and surveys of vikingage Polish sites includes a plethora of Scandinavian-style amulet artefacts such as miniature weapons and cultic objects, attesting to the far-reaching impact of perceived supernatural agencies upon cognitive realities across the medieval North. ${ }^{4}$ As these personal objects spread by travel and by trade, so did their stories, accruing new cultural associations and re-appropriations as they entered new places and changed ownership. How do personal items such as these, with or without perceived magic associations, contribute to cultural constructions of personhood and identities in the medieval North?

This article contributes to ongoing discourse on viking-age identity formations by taking this question as a point of departure, bringing it in dialogue with literary depictions of magic artefacts in saga literature. I contend that Icelandic sagas offer auspicious sites for examining medieval Norse attitudes towards personal objects and their perceived effects upon their users. Old Norse literary sources repeatedly depict material artefacts as animate, imbued with ambiguous agency as if possessing self-determination. The most notorious of these, and featuring across many sagas, are magic swords, which not only are given names but are also portrayed with individual characteristics and behaviours as if characters in their own right. In Grettis saga, Grettir clenches his sword even after his hand is severed from his arm after death, as if the blade is an extension of his body. In Бórðar saga hreðu, an enterprising viking breaking into the burial mound of Hrólfr kraki and his champions fails to reclaim Böðvarr bjarki’s sword Laufi "pví at hann fekk hvergi sveigt hans

burials with classic Norse elements" (W. Duczko: Viking-Age Wolin (Wollin) in the Norse Context..., p. 148).

2 See, for instance, Social Norms in Medieval Scandinavia. Eds. J. Morawiec, A. JochYMEK, G. BARTUSIK. Leeds 2019.

${ }^{3}$ Such as the studies of K. Szajnocha: Lechicki poczatek Polski. Lwów 1858; K. WACHowski: Jomsborg. Normannowie wobec Polski w X w. Studyum historyczne. Warszawa 1914.

${ }^{4}$ For documentation and an extensive catalogue of Scandinavian amulets from Polish sites, see L. Gardela: Scandinavian Amulets in Viking Age Poland. "Collectio Archaeologica Ressoviensis" 2014, Vol. 33. 
armleggi." ${ }^{5}$ In Gísla saga, the sword Grásiða shatters to pieces when it is used to kill its original owner - so much was this weapon a part of him that it could not autonomously exist without its true bearer. Where does one end and the other begin? Given that supernatural phenomena depicted in Old Norse sagas are becoming increasingly recognised as forming integral part of the medieval Norse ontological orientation, ${ }^{6}$ it becomes possible to posit the supernatural as playing a role in cultural constructions of medieval Norse self and personhood. Given that the concept of the self as a centralised autonomous locus of lived experience is a fairly recent phenomenon, it is not to be assumed that premodern selves were conceived of as identical to ours.

Recently posited reassessments of mind and materiality in cognitive science lead to a reconfiguration of the self as embodied and extended, bearing fruitful ramifications for medieval Norse textual depictions of material artefacts - which have heretofore been overwhelmingly banished by literary critics to the realm of symbol or allegory. Medieval saga depictions of supernatural objects as "other," imbued with personhood and possessing agentive properties of their own, highlight the active role of objects in shaping and renegotiating human personal boundaries and self-experiences. It is proposed that an enquiry into depictions of these supernatural objects, as well as of psychosomatic dynamics brought about by characters' interactions with said objects, will open doors towards investigating ecological entanglements between cognitive and material spaces across the medieval North, stressing cross-cultural variability and diversity inherent in medieval worldviews.

\section{Material Engagement}

The perceived power of objects to "act" - in other words, exert influence over people - has been well noted in anthropological studies going back to Marcel Mauss's classic work on gift exchange, yet for most of the $20^{\text {th }}$ century such studies' anthropomorphic scope regarded objects as mere proxies

${ }^{5}$ Pórðar saga hreðu. In: Kjalnesinga saga. Ed. JóHAnnes Halldórsson. Íslenzk fornrit 14. Reykjavík 1959, p. 169: “because no matter what he couldn’t lift his arm.” All translations here and henceforth mine unless otherwise noted.

${ }^{6}$ For latest state of the art on the subject of Old Norse paranormal experiences, see M. Mayburd: The Paranormal. In: The Routledge Research Companion to the Medieval Icelandic Sagas. Eds. Ármann Jakobsson, SverRIR Jakobsson. New York 2017. 
to human processes. ${ }^{7}$ It is only in recent decades that the matter of personhood and material agency has been undergoing radical reassessments and reconceptualisations in fields as diverse as psychology, neuroscience, philosophy, and anthropology, not infrequently birthing contradictory models yet all of them in staunch opposition to the Cartesian bias that has become the de facto personhood standard in the West, which abstractalises mind as contained "inside" the body and isolates body as closed off and external vis-à-vis the "outside" world. Such currently active hypotheses as extended self, ${ }^{8}$ embodied mind, ${ }^{9}$ and extended mind ${ }^{10}$ reconfigure human self as forming a dynamic interactive organism with its environment and with material objects operating in same environment, all pointing to the tensions and complexities that undermine and unravel the seemingly streamlined model of Cartesian cogito. These new approaches seek to de-anthropomorphise and de-hierarchise relational networks between objects and users. ${ }^{11}$ Spilling over from cognitive science, these currents have exercised an immense impact on archaeological theory given their implications for engaging material culture and cognitive structures of past societies.

In his seminal 2004 work Archaeology of Personhood, Chris Fowler coins several terms as working tools for approaching cultural identities unfamiliar with Cartesian mind-body dualism, meant less to define than to illustrate inherent complexities underlining them. In juxtaposition to individuality as an autonomous locus of self-experience, the de facto mode of personhood still overwhelmingly favoured in social sciences, he introduces the construct of dividuality: "a state of being in which a person is recognized as composite and multiply-authored."12 Dividual personhood may manifest as "partibility" (wherein the person is "reconfigured so that one part can be extracted and given to another") and "permeability" (wherein the person is permeated by qualities or entities shaping one's composition). In a dividual state of being, furthermore, "the component parts of the person are not identifiable as objects but as a flow

${ }^{7}$ M. Mauss: The Gift: The Form and Reason for Exchange in Archaic Societies. Transl. by W.D. Halls with a foreword by M. Douglas. New York 1990 (Original publ. 1925); A. Appadurai: The Social Life of Things: Commodities in Cultural Perspective. Cambridge 1988; A. Gell: Art and Agency: An Anthropological Theory. Oxford 1998.

${ }^{8}$ R.W. BelK: Possessions and the Extended Self. "Journal of Consumer Research" 1988, Vol. 15; The Cognitive Life of Things: Recasting the Boundaries of the Mind. Eds. L. Malafouris, R. Renfrew. Cambridge 2010; L. Malafouris: How Things Shape the Mind: A Theory of Material Engagement. Cambridge, Massachusetts 2013.

9 S. Gallagher: How the Body Shapes the Mind. Oxford 2006.

10 A. Clark, D.J. Chalmers: Extended Mind. "Analysis" 1998, Vol. 58, No. 1.

${ }^{11}$ C. Gosden: What Do Objects Want? "Journal of Archaeological Method and Theory" 2005, Vol. 12, No. 3.

${ }^{12}$ C. Fowler: The Archaeology of Personhood: An Anthropological Approach. LondonNew York 2014, p. 8. 
of substances."13 This startling de-anthropomorphisation of personhood essentially turns the focus away from human actants and onto dynamic processes, confluences, and networks all participating in its negotiation. Personhood thus emerges not as a static state but a fluid process of being, continuously shaped and reconfigured by its contextual affordances. Such modes of personhood are, moreover, not limited to humans and are applicable just as well to any nonhuman agencies involved in these processes, be it animals, places, or objects. ${ }^{14}$ Discrete individuality and unity of self is thus a mere historico-cultural construct in its own right, yet so ingrained into discursive framework of modernity as to be near universally taken for granted.

The Cartesian view of the self, from the modern Western socio-normative perspective, has often been uncritically assumed in Old Norse literary scholarship as a point of departure when approaching medieval personhood, resulting in "corporeal reductionism" 15 where the body's physicality fades from view in favour of literary metaphors and notions that "human agents are disembodied minds unaffected by their senses." 16 A similar turn may be noted in saga studies when it comes to crafted objects featuring in the texts, with a tendency to abstractalise them and turn them into symbols and literary motifs, away from the perceived tangible presence these objects exercised - both inside the texts for the characters, and outside the texts for their contemporary audiences. Thus, the dwarf-crafted sword Tyrfingr from Hervarar saga has been interpreted as little else than "phallic"17 or "emblematic of fallen patriarchy,"18 while a notch in the blade of the magic sword Sköfnungr in Kormáks saga has been claimed to represent "sexual dysfunction" of the latter saga's eponymous protagonist. ${ }^{19}$ Needless to say, such puerile attempts at discursive closure do little justice to the rich potential there is to explore in saga depictions of crafted objects (swords and otherwise) and their "social lives" as experienced by human users.

It is only recently that this started to change. A growing number of anthropological and cultural-historical studies of pre-modern societies have been moving away from Cartesian paradigms, putting literary sources in dialogue with their respective cultures' material ontologies and demonstrating pre-modern

${ }^{13}$ C. Fowler: The Archaeology of Personhood..., p. 9.

${ }^{14}$ C. Fowler: The Archaeology of Personhood..., pp. 101-130.

${ }^{15}$ C. Shilling: The Body in Culture, Technology and Society. London 2004.

${ }^{16}$ L. Stark: The Magical Self: Body, Society, and the Supernatural in Early Modern Rural Finland. Helsinki 2006 (Folklore Fellows' Communication, Vol. 290), p. 146.

${ }^{17}$ C.J. Clover: Maiden Warriors and Other Sons. "The Journal of English and Germanic Philology" 1986, Vol. 85, No. 1, p. 38.

18 W. LAYHer: Caught Between Worlds: Gendering the Maiden Warrior in Old Norse. In: Women and Medieval Epic: Gender, Genre, and the Limits of Epic Masculinity. Eds. S.S. Poor, J.K. Schulman. New York 1997, pp. 196-197.

19 W. SAYers: Sexual Identity, Cultural Integrity, Verbal and Other Magic in Episodes from Laxdoela saga and Kórmaks saga. "Arkiv för nordisk filologi” 1992, Vol. 107, p. 145. 
conceptions of personhood to be far more fluid and malleable than heretofore thought, where boundaries between self and surrounding world were less strictly defined and indeed may not have existed as we understand them today. ${ }^{20}$ In pre-modern ontological orientations, the self was considered malleable, lacking clear boundaries and being vulnerable, in its openness, to perceived intrusions. The physical human body thus becomes an "open body," and the outside is thus no longer external to it, but rather an extended space of this malleable human self. Throughout medieval Europe, physical environment was regarded as ominous, filled with ambiguous other-than-human agencies and forces that can threaten or attack the body at any moment. ${ }^{21}$ The perceived supernatural influence and presence of magic objects only spells out that bodies were exposed to, and subject to, these influences as well. Indeed, the medieval worldview was decidedly non-anthropocentric, humans sharing the same environment with other-than-human beings and entities, both organic and inorganic alike. Nor were these beliefs limited to a particular region or vernacular folklore, as they circulated not only in literature but in medical treatises as well, thereby affirming these notions as legitimate daily concerns beyond mere entertainment. In learned medieval medical discourses, attestably known in medieval Iceland as demonstrated by humoural theory found in the early $14^{\text {th }}$-century Hauksbók codex, human body and physical world were regarded in a dialogic relation to each other as microcosm and macrocosm, both comprised of the same natural elements, with their mutual entanglements and interdependencies enabling environmental influences to affect the body's "internal microclimate." 22

Symptomatic of these ecological sensibilities, resortions to amulets and talismanic objects may be regarded as efforts to establish symbiotic relationships between human and nonhuman agents in their shared environment, in order to mitigate the myriad dangers to human health and welfare that the same ambivalent environment is also quite adept at conjuring. Stones were widely employed for talismanic purposes throughout medieval Europe, and their properties were just as widely narrated and circulated in mineralogical treatises known as lapidaries. Knowledge of these has made its way to medieval Scandinavia as well: Hauksbók contains a lapidary treatise on agentive

20 See, for instance, such groundbreaking studies as N. PricE: The Viking Way. Magic and Mind in Late Iron Age. Oxford 2019 for late Iron-Age Scandinavia; L. StARK: The Magical Self... for early modern Finland; L. Malafouris: Is It "Me" or Is It "Mine"? The Mycenaean Sword as a Body-part. In: Past Bodies: Body Centered Research in Archaeology. Eds. J. RoвB, D. Boric. Oxford 2008 for ancient Greece; and K. Kanerva: Porous Bodies, Porous Minds. Emotions and the Supernatural in Íslendingasögur (ca. 1200-1400). "Annales Universitatis Turkuensis" 2015, Vol. 398 for medieval Iceland.

${ }^{21}$ L. Stark: The Charmer's Body and Behaviour as a Window onto Early Modern Selfhood. In: Charms, Charmers, and Charming: International Research on Verbal Magic. Ed. J. Roper. Hampshire-New York 2009, p. 13.

22 K. Kanerva: Porous Bodies, Porous Minds..., p. 95. 
properties of precious stones, demonstrating once more that interest in such matters pervaded all social strata. ${ }^{23}$ Nor was it limited to speculative discourse: archaeological data from settlement-era Iceland points to stones being used as personal amulets. Póra Pétursdóttir's study of Icelandic pagan graves shows that "such items are actually among the most commonly found grave goods," attested in 21 burials, "but are most likely underrepresented as they can easily be overlooked or ignored during excavations." ${ }^{24}$ This finding comes from the dataset of nearly 300 Icelandic pagan graves identified and documented by Kristján Eldjárn in his 1956 thesis Kuml og Haugfé, which makes no mention of them. ${ }^{25}$ Discerning a deliberate placement of raw unshaped stones in graves is much like searching for a hay needle in a haystack, yet closer scrutiny reveals their placement to be deliberate indeed. Upon examining these 21 graves, Elizabeth Ida Ward observes that "small, mostly unworked, native Icelandic stones" were found in close proximity to bodies of buried individuals, namely near their hips, the same spots where fire-strikers were sometimes also discovered. Such placements suggest these items "were carried in small pouches on a belt, and that this belt and pouch were thought of as personal items of the deceased which were therefore buried with them."26 Ward further notes these stones were sourced "directly from the Icelandic landscape, presumably from mountain sides given the crystalline rocks involved (although precise sourcing was not possible)," suggesting they linked their users to vital forces of such zones. ${ }^{27}$ Given these stones' careful placement in pagan burials, they are "directly linked to non-Christian beliefs" and thus "clearly personal items; it is therefore likely these small objects operated agentively in a private setting." 28

Curiously, medieval Icelandic sagas make repeated mentions of healing stones (lyfsteinn, lit. "life-stone"), which tend to accompany renowned swords and offer the only cures for the otherwise fatal wounds these weapons inflict. In

${ }^{23}$ AM 544 4to, 34r. See Hauksbók, udg. efter de Arnamagnceanske håndskrifter no. 371, $544 \operatorname{og} 675,4{ }^{\circ}$ samt forskellige papirshåndskrifter af det Kongelige nordiske oldskrift-selskab. Eds. Eiríkur Jónsson, Finnur Jónsson. København 1892-1896, pp. 227—228. For more on mineral powers and their reflections in Old Norse myths and sagas, see M. MaYBuRD: Between a Rock and a Soft Place: Materiality of Old Norse Dwarves and Paranormal Ecologies in fornaldarsögur. In: Supernatural Encounters in Old Norse Literature and Tradition. Eds. D. Savborg, K. Bek-Pedersen. Turnhout 2018.

${ }^{24}$ PÓRA Pétursdóttir: "Deyr fé, deyja frcendr": Re-animating Mortuary Remains from Viking Age Iceland. MA thesis, University of Tromsø 2007, p. 81.

${ }_{25}$ The revised and expanded 2000 second edition of Kuml og Haugfé did not include these stones in its survey as well.

${ }^{26}$ E.I. WARD: Nested Narrative: Dórðar saga hreðu and Material Engagement. PhD thesis, University of California, Berkeley 2012, p. 47.

27 E.I. WARD: Nested Narrative..., p. 48.

28 E.I. WARD: Nested Narrative..., p. 48. 
Kormáks saga, Bersi's sword Hvítingur has such a lyfsteinn, ${ }^{29}$ and in Laxdcela saga the legendary sword Sköfnungr is noted to have a lyfsteinn as well. ${ }^{30}$ The latter text offers a rare glimpse of this stone in use: "Pórkell sér, at Grím mœðir blóðrás; tekr pá Sköfnungs-stein ok riðr ok bindr við hönd Gríms, ok tók pegar allan sviða ok prota ór sárinu." ${ }^{31}$ Although sagas are silent on how such stones were kept, the sword Sköfnungr is noted to come with a pouch tied to it as an accessory ("pungr fylgir, ok skaltu hann kyrran láta"), ${ }^{32}$ which suggests it may have hosted the lyfsteinn inside. Regardless of the pouch's content, the sword itself thus becomes a composite entity - a micro-ecology in its own right, to be treated with care and respect. Not only does the lyfsteinn form a symbiotic relationship with the human body, but here too is a symbiosis between the stone and the sword. To what extent does physical proximity to the sword infuse the stone with the sword's essence, granting the stone sole authority to override the sword's deadly bite? Just as the stone is directly sourced from the natural environment, so is the sword itself — in the state of natural materials that were shaped by craftsmanship into this present form. What appears to be a single inert object to a modern reader accustomed to consumerism of mass production suddenly becomes a kaleidoscopic site of dynamic activity blurring boundaries between multiple entities involved. ${ }^{33}$

With artisan craftsmanship (which, of course, does not "produce" but rather refines pre-existing materials), another ambiguous layer of agency enters the frame: that of the crafter who gives the artefact its form. The notion of artisan transferring something of oneself into the crafted piece has led the figure of the smith to be associated with magic powers in folklore across the medieval North, ${ }^{34}$ and hence the supernatural origins oft attributed to renowned swords. With artisan craftsmanship, mobilities and traffic enter the frame as well. Crafted objects travel, whether by trade, gift exchange, theft, or other means; they may change owners or they may simply be carried to new places by original

${ }^{29}$ Kormáks saga. In: Vatnsdaela saga. Ed. EINAR ÓlaFur Sveinsson. Íslenzk fornrit 8. Reykjavík 1939, ch. 9, p. 234.

${ }^{30}$ Laxdcela saga. Ed. EINAR Ólafur Sveinsson. Íslenzk fornrit 5. Reykjavík 1934, ch. 58, p. 172 .

31 Laxdcela saga..., p. 173: "Pórkell sees that Grímr is tiring from blood loss; then he takes the Sköfnungr-stone and rubs it and binds it to Grímr's hand, and it immediately took all the pain and swelling out of the wound."

${ }^{32}$ Kormáks saga..., p. 235: "a pouch comes with it, and you should leave it undisturbed." Never one to follow instructions, Kormákr later rips the pouch off the scabbard.

33 See T. InGOLD: Rethinking the Animate, Re-animating Thought. "Ethnos: Journal of Anthropology" 2006, Vol. 71, No. 1 for a lucid phenomenological reassessment of materiality, wherein he criticises its conceptual abstraction and restores primacy to the experience of materials themselves.

34 See L. Motz: The Wise One of the Mountain: Form, Function, and Significance of the Subterranean Smith. A Study in Folklore. Göppingen 1983. 
owners, but in all cases the schemata of their local ecologies are continuously altered and expanded, enabling new composite networks and entanglements to emerge. In the Íslendingasögur and medieval Icelandic historical chronicles, all renowned swords that have names and are wielded by Icelandic characters are originally obtained abroad, in Europe. The fabled quality and exoticism of these swords, their scarcity in medieval Iceland, and their associative links with supernatural craftsmanship may have contributed to these weapons being perceived as potential agents of otherness, the materials of which are sourced from ambiguous inhospitable environment and which are transmuted into these deadly shapes by arcane metallurgical processes. The tension generated by their presence is what Jane Bennett has called "a shimmering, potentially violent vitality intrinsic to [all] matter." ${ }^{35}$ Let us now see what happens when these swords pass hands and change users, and how the former's coming in physical contact with the latter was portrayed in the sagas.

\section{Bane-blades and Their Psychosomatic Effects}

The sword Tyrfingr in Hervarar saga is perhaps the most notorious legendary sword in Old Norse lore. That it had a rich and storied history is attested by the saga narrator declaring "Petta sverð er frægt 1 öllum fornsögum,," ${ }^{36}$ an effective reminder today that the extant Old Norse saga corpus is but a fragmentary remnant of a vaster body of tales now lost, whether by their transmission going unrecorded or by their manuscripts perishing in the passage of time. Hervarar saga is extant in two manuscript variants, the oldest of which dates to first quarter of the $14^{\text {th }}$ century and the younger to the $15^{\text {th }}$. Their at times substantial differences in plot details indicate how vibrant and dynamic these legends were in contemporary circulation (on which more below). The implicit popularity of the story of Tyrfingr among medieval audiences was resoundly echoed in its post-medieval reception. ${ }^{37}$ Hervarar saga was among the very

35 J. Bennett: Vibrant Matter. A Political Ecology of Things. Durham-London 2010, p. 61.

${ }^{36}$ Hervarar saga ok Heiðreks. Eds. G. Turville-Petre, C. Tolkien. London 1956, p. 2 : "this sword is renowned in all ancient sagas."

${ }^{37}$ C.E. Fell: The First Publication of Old Norse Literature in England and Its Relation to Its Sources. In: The Waking of Angantyr: The Scandinavian Past in European Culture. Eds. E. Roesdahl, P.M. Sørensen, Aarhus 1996 (Acta Jutlandica Vol. LXXI, No. 1. Humanities Series 70). 
first Old Norse texts to appear in early modern printed editions, and was prized by antiquarians for its iconic scene of Hervör summoning and confronting her dead father Angantýr - a fearsome berserker who once wielded Tyrfingr and was buried with it - to reclaim this sword for herself. ${ }^{38}$ Given the saga's drama, it is perhaps not surprising this sword tends to "disappear" in literary interpretations which overwhelmingly focus on human events and are only interested in Tyrfingr insofar as its narrative functions as a plot catalyst or a generational heirloom. But what of this sword's actual physical presence inside its narrative world? Closer scrutiny of it is now warranted.

There is a discrepancy between the two saga variants in how Tyrfingr is introduced. What is consistent between them are the properties that have made this sword legendary: it brings victory in battles and brings death every time it is unsheathed. The younger manuscript adds that "hvert sin, er pví var brugðit, pá lýsti af svá sem af sólargeisla" and that "með vörmu blóði skyldi hann jafnan slíðra," ${ }^{39}$ which suggest it behaves and reacts in certain ways under certain conditions, and must be handled accordingly. The older manuscript unfolds Tyrfingr's origin story missing from the younger version: king Svafrlami traps two dwarves and coerces them into crafting him a sword "pat skal svá bíta járn sem klæði ok aldri ryðr á festaz; pví skal fylgja sigr í orrostum ok einvígjum hverjum er berr." ${ }^{\prime 40}$ This negative atmosphere of duress results in a spitefullymade artefact loaded with the malice of its makers, both of whom add a curse:

"sverð pitt, Svaframi, verðr mannz bani hvert sinn er brugðið er, ok með pví skolu unnin vera prjú níðingsverk, pat skal ok verða pinn bani." Pá hjó konungr sverðinnu til dverganna; hlupu peir í steininn; höggit kom ok í steinnin ok fal báða eggteina, bví at dyrrnar lukuz aptr á steininum. ${ }^{41}$

${ }^{38}$ A thorough analysis of this saga scene, as well as of its reception in $20^{\text {th }}$ century literary scholarship, is offered in M. MAYBURD: "Helzt póttumk nú heima i millim..." A Reassessment of Hervör in Light of seiðr's Supernatural Gender Dynamics. "Arkiv för nordisk filologi” 2014, Vol. 129, pp. 121-164.

${ }^{39}$ Hervarar saga ok Heiðreks..., p. 2: "each time it was drawn, it shone like the sun's rays"; "in warm blood must it always be sheathed." Notably, the original Old Norse uses passive voice to describe Tyrfingr's shining (lit. "there shined from it as from the sun's rays"), as if pointing to some unnamed power responsible for this. Instead of being depicted as merely animate, Tyrfingr emerges here as a composite entity that is animated by undisclosed paranormal agencies, adding yet another layer of ominous ambiguity and making this sword all the more treacherous.

${ }^{40}$ Hervarar saga ok Heiðreks konungs. Ed. Jón Helgason. København 1924, p. 3: "which should bite iron as if it were clothing and never rust; victory in battles and duels should follow the one who bears it."

${ }^{41}$ Hervarar saga ok Heiðreks konungs..., p. 3: “"your sword, Svafrlami, will be a man's bane each time it is drawn, and with it will be done three despicable acts, it will also be your death.' Then the king struck at the dwarves with the sword; they leaped into the stone; the strike came at the stone and hid both edges of the blade, as the doors of the stone closed shut." 
This scene, entirely omitted in the saga's other variant, imbues Tyrfingr with a sinister undercurrent which turns what may have simply been its magic properties into terrible doom that continues to hover over this sword throughout its history. The passing detail of the blade momentarily submerging in the stone from the blow's momentum (was it not supposed to cut through hard surfaces as if through cloth?) adds an eerie tinge to the narrative, reminding this sword is allied with paranormal forces and might not always serve its wielder.

Tyrfingr's influence on the folkloric trope of cursed magic swords possessing self-determination may be recognised in such medievalist fantasy reimaginings as Stormbringer in Michael Moorcock's Elric of Melniboné - the black sword sustaining its sickly owner at the cost of perpetually feeding it lives, and Gurthang in J.R.R. Tolkien's The Silmarillion - the cursed sword of Turin doomed to kill friends and foes alike. ${ }^{42}$ The latter blade was based on the sword of Kullervo from the Finnish folk epic The Kalevala, where the sword's wielder intends suicide and queries his weapon for its willingness to drink his blood; the sword confirms in animate speech its eagerness to do so. ${ }^{43}$ While such moments are skilfully drawn for poetic effect, there is inherent tension in this personification as a suicidal mind strains to establish a symbiotic relationship with a killing instrument. Talking to a weapon, and hearing it talk back, betrays the character's psychological unease in deferring agency over one's own life to an object which, if not imbued with sentience, is subjectively perceived in those terms by the wielder. The fear of dying alone and hence projecting animacy on a thing to make a witness out of it are illustrative of the disturbing permeability of the human mind, no longer an autonomous actant agent but porous and open (cracked open, perhaps, by the stress it undergoes), willing to fuse with an inanimate object in a critical moment to the point that it becomes animate indeed. Something of oneself is now distributed in this new bodyobject network, as if the latter completes the former. In imbuing a weapon with its own agentive properties, its owner is essentially fragmenting oneself into these composite, and perceivedly autonomous, parts. It bears keeping this selffragmentation dynamic in mind, as it will be revisited at greater length below.

The sword Tyrfingr in Hervarar saga does not speak, but exudes a distinct fatal charisma of its own. Though seldom featuring in spotlight, its silent presence haunts the interstices of the narrative, leaving side-effects upon the minds and bodies of human characters who come in touch with it. After Hervör recovers Tyrfingr for herself, its doom of taking a life each time it is drawn binds her in a cycle of bloodshed: when an unsuspecting bystander at a royal court unsheathes Tyrfingr to admire its blade, Hervör slays him at once as if

${ }^{42}$ M. Moorcock: Elric of Melniboné. London 1972; J.R.R. Tolkien: The Silmarillion. London 1977.

${ }_{43}$ The Kalevala. The Epic Poem of Finland. Transl. by J.M. Crawford. New York 1888, Rune XXXI, p. 561. 
purely on compulsion, in full disregard of context or consequence. The saga goes to great length to narratively establish her aversion to feminine activities extending as far back as her childhood, yet after spending considerable time in viking campaigns in the wake of reclaiming Tyrfingr she nevertheless abandons this military life, returning home and taking up "spinning and weaving" at first glance, in complete contradiction to her narratively established personality. ${ }^{44}$ The saga qualifies this turnaround by saying of her pursuit of warfare that "henni leiddiz pat" ("it wearied her") 45 — wherein the sense that she got tired of it can also imply exhaustion and not mere boredom. This opens the door to considering the psychosomatic toll such activities exert in the form of post-traumatic stress and related phenomena. As an active combatant, Hervör was armed not with any generic weapon but with the legendary bloodthirsty sword compelling its wielder to kill each time it is unsheathed. To what extent was her "weariness" no mere combat fatigue, but the result of being drained under the sword's eerie parasitic influences?

The notion of particular weapons over-exerting or draining their wielders was not foreign to Old Norse imagination. In Hrólfs saga kraka, the sword Laufi is said to be so demanding that the same person can only wield it thrice, so difficult was its nature. ${ }^{46}$ Like Tyrfingr, it likewise could not be unsheathed without killing. We may recall Laufi gripped tightly by Böðvarr's arm even in death, as if they were fused together. Yet instead of reading this as attestation of Böðvarr's fortitude and willpower, it is perhaps not out of place to read this dynamic in reverse: attesting rather to this sword's completion of its "user cycle," utterly consuming him to the point of merging with his body so as to become entirely unmovable and unusable. While Tyrfingr is never mentioned to have a similar usage restriction, its own characteristics do strongly imply its wielder cannot remain unaffected, becoming an extension of the sword and its agency rather than vice versa - a mere surrogate carrier for this parasitic entity to act out its prescribed dynamic pattern of violence and blood. Viewed from this perspective, Hervör's homecoming and uncharacteristic immersion into "spinning and weaving" emerge as darker indications of a war veteran's attempt to create separation from incurred combat trauma, seeking to distance oneself from triggering or aggravating it further. As if by own volition, Hervör now takes a step back in the narrative, making way for a new set of characters to emerge not least of which is her son Heiðrekr. Yet the sword Tyrfingr continues to remain in her possession, and she is not out of the saga just yet.

What happens next with Tyrfingr is one of several scenes that vary dramatically between Hervarar saga's two extant manuscript versions. As this

${ }^{44}$ Hervarar saga ok Heiðreks konungs..., p. 34.

${ }^{45}$ Hervarar saga ok Heiðreks konungs..., p. 34

${ }^{46}$ Hrólfs saga kraka. In: Fornaldar sögur Nordrlanda eptir Gömlum Handritum. Vol. 1. Ed. C.C. RAFN. Kaupmannahöfn 1829, ch. 31, p. 61. 
critical scene considerably impacts audience perception of both the plot and the characters, it bears at this juncture to carefully delineate both variants. The younger manuscript's version of events requires the least introduction as it is the most familiar to modern readership, being the source of Christopher Tolkien's English translation and standardised edition of the saga. ${ }^{47}$ In this version, the troublemaker Heiðrekr throws a stone in the dark in the direction of a human gathering; it fatally hits his brother Angantýr (named after their berserker grandfather), who happened to be standing in its orbit, and this fratricide leads to Heiðrekr's banishment by his father. Prior to Heiðrekr's departure, Hervör grants him the sword Tyrfingr and instructs him in its usage, coming across in this act as more of a father figure to him than his actual one.

This younger saga version's sparce narrative style and streamlined plot management were favoured by early philologists over the long-winded and meandering older version. This tacit editorial bias has been overwhelmingly responsible for shaping general audience reception of Hervarar saga to the point many lay readers (and even saga critics) remain unaware it is not the only way this story was told in medieval times. This perception is aggravated further by Christopher Tolkien strangely omitting the alternate version of this scene from his appendix of documented saga variants, translations of which he includes in his edition.

The older manuscript's account of Heiðrekr's fratricide differs so radically it is worth citing in full. It is only preserved in the Hauksbók codex, wherein this saga was included in incomplete form. ${ }^{48}$ In this variant, Heiðrekr's troubled character comes through in a series of killings which prompt his father to declare him an outlaw, whereupon the following events unfold:

Gekk pá Heiðrekr út ok með honum bróðir hans; par kom pá móðir hans ok fekk honum Tyrfing. Pá mælti Heiðrekr: "eigi veit ek, nær ek get svá mikinn mun gert föður míns ok móður, sem pau gera mín; faðir minn gerir mik útlægjan, en móðir mín gaf mér Tyrfing, er mér pykkir betra en mikit ríki, ok skal ek gera pat eitthvert, er honum má verst pykkja." Hann brá pa sverðinu, ok lýsti af mjök ok sindraði; hann eiskraði pá mjök, ok hélt við berserksgang. Nú með pví at peir broeðir váru tveir saman, en Tyrfingr varð mannz bani hvern tíma, er honum war brugðit, pá hjó hann bróður sinn banahögg." ${ }^{\text {49 }}$

${ }^{47}$ The Saga of King Heidrek the Wise. Saga Heidreks konungs ins Vitra. Ed. and transl. by C. ToLKIEN. London 1960. The original Old Norse text of the saga's younger version facing the translation is reprinted from the 1956 edition of Hervarar saga ok Heiðreks...

48 This is the so-called manuscript variant H in AM 544 4to; this fragment runs from the beginning of the saga and stops just after Gestumblindi's riddle contest.

${ }^{49}$ Hervarar saga ok Heiðreks konungs..., p. 36: "Heiðrekr went outside, and his brother with him. Then his mother came and gave him Tyrfingr. Then said Heiðrekr: 'I don't know when I'll do as much for my father and mother, as they have done for me; my father made me an outlaw, but my mother gave me Tyrfingr, which I think is better than a great kingdom, and I shall 
If we accept this saga version as a legitimate and self-contained narrative in its own right (and not as any kind of derivation or dilution, as early philologists tended to do), it offers fascinating nuances of characterisation shedding a different perspective on the plot. Hervör's seemingly haphazard appearance (and disappearance, for the brothers were left alone) and her seemingly random giving of the sword as if it were an ordinary thing do not at all have to indicate poor plot management. Keeping in line with the above observations on the psychosomatic toll Tyrfingr exerts as well as Hervör's impacted state after her homecoming, is her act not an apt illustration of how a long-time war veteran might behave handling weapons, so desensitised to violence that an implement of killing (and ancient family heirloom) is indeed bestowed almost at random as if it were a trivial toy? If its bestowal was a token of favour in reaction to Heiðrekr's outlawry, then the brothers' going outside is indicative of exchanging farewells before Heiðrekr's departure: viewed in this light, his sudden fratricide is all the more shocking. The staging of the scene explicitly indicates the violent urge entered his mind only after Tyrfingr was in his hand - he did not deliberately seek out his brother, the latter simply followed him and they happened to be alone.

The striking mention of berserksgangr (berserk frenzy, lit. "going berserk") at the sight of Tyrfingr's naked blade is all the more extraordinary given Heiðrekr's temperament. He may be prone to occasional sociopathy, but his personality is that of a sly and wily mind, not a raging maniac. Seeing this character - inn vitri, as he is sometimes called ("the wise") — so radically transformed by Tyrfingr in his hand makes one wonder to what extent he is still himself, and indeed which part of himself, if any, is truly his own. It bears remembering one of the sword's previous owners, his own grandfather, was a fearsome berserker. How much of that previous owner is left in this sword now? Is it indeed Tyrfingr prompting Heiðrekr to kill, or is Heiðrekr coming in physical touch with ancestral memories embedded in this blade, ones that were not his own but have disturbingly indeed become his, pulling out of him a murderous fury he never experienced before nor since? If the touch of the handle loaded his mind with violent intent, the sword's shining upon unsheathing, as if in anticipation, is the trigger catapulting him into a neurological state beyond recovery. He is not wielding Tyrfingr: it appears to be quite expertly wielding him. Yet their relation is not dialogical: it is eerily plural, for the person known as Heiðrekr inn vitri momentarily dissolves into a composite assemblage of

do something that he will consider the worst.' Then he drew the sword, and it shone greatly and glowed; he screamed then mightily and carried on with berserk-frenzy. Now due to the brothers being alone together, and Tyrfingr being a person's death each time it was drawn, then he struck his brother a killing blow." It is worth noting that C.C. Rafn's 1829 normalised edition of Hervarar saga loosely follows the Hauksbók version for this scene, but entirely omits the details of Tyrfingr's shining and its bodily-mental impact of berserker rage on Heiðrekr as he draws it. 
agencies and identities, in which are entangled the context of sword's craftsmanship, its origin and its alliance with paranormal forces, experiences and memories of its previous owners, his own bloodline and its possibly dormant berserker potential (to what extent may this even be considered human?), and the sword's present reactions to his touch and movement. Was the singular nature of his personhood an illusion all along? In attributing Heiðrekr's act to agency of Tyrfingr, the narrator of this saga variant appears to be in agreement. Tyrfingr is itself composite and multiple, all of its own past circumstances and "experiences" presently converging in its physical form.

The dynamic of distributed personhood - of objects, not only of their users - speaks to the slippery slope of the unitary self-concept, uncomfortably exposing it as a contingent construct not any less fictional than its alternatives. It is not surprising to find this paranormal dynamic widely appropriated in literature up to the present times, such as the following scene from Tolkien's The Fellowship of the Ring when an otherwise pragmatic level-headed character comes in physical touch with an arcane artefact:

"What in the name of wonder?" began Merry, feeling the golden circlet that had slipped over one eye. Then he stopped, and a shadow came over his face, and he closed his eyes. "Of course, I remember!" he said. "The men of Carn Dûm came on us at night, and we were worsted. Ah! the spear in my heart!" He clutched at his breast. "No! No!" he said, opening his eyes. "What am I saying? I have been dreaming. ${ }^{\circ 0}$

As a scholar of Old English, Tolkien was well familiar with ambivalence and apprehension in medieval narratives surrounding artefacts from a yet deeper past. An open landscape of ancient mounds and barrows made Anglo-Saxon England, much like medieval Scandinavia, a plethora of nested temporal layers for their contemporary audiences, a feature which in recent years has been attracting renewed critical attention. ${ }^{51}$

The fears of being influenced by something exuding from artefacts forms the premise of sympathetic magic, as multiple studies note. ${ }^{52}$ What is inherent

50 J.R.R. Tolkien: The Fellowship of the Ring. Part I of The Lord of the Rings. New York 1965, p. 198.

${ }_{51}$ See S. Semple: Perceptions of the Prehistoric in Anglo-Saxon England: Religion, Ritual, and Rulership in the Landscape. Oxford 2012. For medieval Norse perceptions of the raw uninhabitable Icelandic terrain and its mound-resembling hills as sites blurring distinctions between this world and otherworld, see M. Mayburd: The Hills Have Eyes: Post-Mortem Mountain Dwelling and the (Super)natural Landscapes in Íslendingasðgur. "Viking and Medieval Scandinavia" 2014, Vol. 10.

52 W.L. Hildburgh: Psychology Underlying the Employment of Amulets in Europe. "Folklore" 1950-1951, Vols 51-52; P. Rozin, C.J. Nemeroff, M. Wane, A. Sherrod: Operation of the Sympathetic Magical Law of Contagion in Interpersonal Attitudes among Americans. 
in these attitudes is the phenomenon of magical contagion, "a cross-cultural tendency to believe that a person's essence can 'rub off' on and contaminate objects that have come into physical contact with a person." ${ }^{53}$ The same dynamic of contagion (albeit in positive light) is also observable in sacred relics effulgently collected and distributed throughout the Middle Ages, as well as the more recent iterations in post-medieval times in the form of historic memorabilia and celebrity-owned items. The personhood of previous owners is transferred into the object, forming an active conduit between said object and its new owner or user. This in turn "suggests that some objects may be seen as extensions of the self because they are imbued with the person's essence," 54 which then begs the question: what happens when an object changes owners, and of whose self is it now an extension? As observed by several studies, what makes a thing feel haunted is the awareness of its existence in multiple prior unfamiliar contexts or passing through multiple owners, whose traces it still perceivedly carries. ${ }^{55}$ Remaining alien to its new user, such an object cannot be seamlessly integrated into one's personal ecology, and such seams are prone to lead a suggestive mind to get caught in them.

\section{Distributed Personhood and Disruption of Self-agency}

This same dynamic of artefact contagion manifests in other Old Norse narratives when benign characters come in physical contact with "loaded" - or haunted - artefacts from deeper past. The $13^{\text {th }}$-century Kumlbúa páttr relates the tale of a peaceful man named borsteinn, married into a priest's family, who finds an old eroded grave in Icelandic countryside one evening on his way home and takes a sword from it. ${ }^{56}$ It is a pagan grave, several centuries removed

"Bulletin of the Psychonomic Society" 1989, Vol. 27; C.J. Nemeroff, P. Rozin: The Contagion Concept in Adult Thinking in the United States: Transmission of Germs and of Interpersonal Influence. "Ethos: Journal of the Society for Psychological Anthropology" 1994, Vol. 22; L. StARK, The Magical Self...

${ }_{53}$ G.E. Newman, D.M. Bartels, R.K. Sмith: Are Artworks More Like People Than Artifacts? Individual Concepts and Their Extensions. "Topics in Cognitive Science" 2014, Vol. 6, No. 4, p. 651.

${ }_{54}^{54}$ G.E. Newman et al.: Are Artworks More Like People Than Artifacts?..., p. 651.

${ }_{55}$ P. Rozin et al.: Operation of the Sympathetic Magical Law of Contagion...; C.J. NemeRoff et al.: The Contagion Concept...; G.E. Newman et al.: Are Artworks More Like People Than Artifacts?...

${ }^{56}$ For more on Kumlbúa páttr in the context of medieval Icelandic worldviews, especially pertaining to multiple temporal layers unfolding and intersecting in this narrative, see 
from the time when the narrative unfolds, as evidenced by its time-ravaged condition exposing its remains, as well as its location in the open landscape. The sword that was part of this burial, which Porsteinn now unearths, belongs in the same deep past as the skeletal remains of its owner. Porsteinn disturbs this local ecology by carrying away something from this spot he should not have touched. This violation is twofold: given his clerical family affiliation, he should not be carrying a weapon into his peaceful home. It is, moreover, no ordinary weapon but a veritable ancient artefact from pagan past, and bringing this alien object into a Christian milieu where it does not belong contributes to the already building tension. In these new surroundings, the sword exerts an ambiguous presence of its own. The uneasiness exuding from its presence makes itself palpable as borsteinn is haunted in his dreams by the sword's owner - who now appears before him touting a large axe, a threatening and formidable sight (not least speaking of the physical fortitude of this apparition, who in the dream takes a fully human form). This sword owner addresses Porsteinn in skaldic verse, meant to intimidate. Yet this peaceful Christian man, a relative of a priest, retorts in the same dream with strong skaldic verses of his own. The sword's original owner is so thoroughly satisfied by this response that he lets the man keep the sword. Yet Porsteinn continues to be troubled in his sleep and finds no ease.

What has happened in the process of that exchange? Is it the sword's bloodthirsty presence nearby that drew such uncharacteristic barrage of versified skaldic violence out of an otherwise non-threatening character? He remains deeply perturbed, finding no peace - all because of making contact with this artefact, something he should not have meddled with. It is not to be discounted that the effortless ease of Porsteinn's skaldic retort had its share in disturbing him. Who was really speaking in that moment? Was he still himself, or did he in that instant become someone else, speaking through him? The sword's original owner addressed him as namni ("namesake") in the dream, as if alleging intimate connection through this sword now shared between them. ${ }^{57}$ Have they become parts of each other, with this apparition a reflection of himself? Haunted by the weapon's eerie presence even after waking, borsteinn seeks to rid himself of the sword by returning it to its rightful place in the mound. Yet his efforts are wasted, for he cannot find that pagan grave ever again. It is not unlikely that his failure to do so stems from his already unstable mental state under the sword's influence. Was it then the sword's agency acting out its resistance to being returned, as if it wills to remain in his keeping? The grave's

M. Mayburd: Kumlbúa páttr and the Paranormal Event. The Traumatic Ontology of Being in Time in Medieval Iceland. In: From Rus' to rimur: New Norse Studies. Ed. S.F.D. Hughes et al. Occasional issue, "New Norse Studies." Ithaca, New York (forthcoming).

${ }^{57}$ Kumlbúa páttr. In: Harðar saga. Eds. PóRHALlur Vilmundarson, BJARNi Vilhjálmsson. Íslenzk fornrit 13. Reykjavík 1991, p. 454. 
seeming disappearance from the countryside is suggestive of a resolution: the buried owner welcomes Porsteinn's possession of the sword and the proverbial door to the otherworld is now shut. It is precisely this familiarity in their relations that scares him - his own lapse of agency throughout these happenings, the permeability of his own mind. There is no closure for the conflicted Porsteinn, who is now stuck with this alien artefact he no longer wants. This sword becomes a witness and a reminder of his traumatic experience - all of which was triggered by carrying away something he should never have touched from its rightful place.

Agentive composite personhood of an object, augmented by ecological violation of its removal from its source, may be further illustrated by the case of the sword Sköfnungr, especially as depicted in Pórðar saga hreðu. Though the oldest manuscript of this saga dates to the first half of the $15^{\text {th }}$ century, stories associated with this sword were well in circulation in medieval Iceland for centuries prior. It is mentioned in as many as five different medieval Icelandic narratives, whose internal consistency speaks to Sköfnungr's endurance in audience imaginations as an object with a unique and recognisable identity of its own. ${ }^{58}$ Originally owned by legendary Danish king Hrólfr kraki, this sword was robbed from his burial mound during the period of Icelandic settlement, as Pórðar saga hreðu relates:

Skeggi var garpr mikill ok einvígismaðr. Han var lengi í víkingu. Ok eitthvert sinn kom hann við Danmörk ok fór til Hleiðrar, pangat sem haugr Hrólfs konungs kraka var, ok braut hauginn ok tók á braut sverðit Hrólfs konungs, Sköfnung, er bezt sverð hefir komit til Íslands [...]. ${ }^{59}$

This was the same scrappy viking entrepreneur from an earlier-cited example who failed to reclaim Böðvarr's sword Laufi in the same mound, although he encountered no similar trouble in taking the axe of Hjalti hugpruði, another champion buried beside the king. Archaeological data suggests that postinterment disturbance of human remains was not uncommon in the viking age, yielding credence to the oft-recurring motif of mound-breaking encountered in sagas. ${ }^{60}$ The saga's remark qualifying Sköfnungr as the best sword to come

${ }^{58}$ Landnámabók, Kormáks saga, Laxdcela saga, Dórðar saga hreðu, Hrólfs saga kraka.

59 Pórðar saga hreðu..., ch. 2, p. 169: "Skeggi was a great hero and dueller. He had been in viking campaigns a long time. And one time he came to Denmark and went to Hleiðar (Lejre), where the mound of king Hrólfr kraki was, and broke into the mound and took from it the sword of king Hrólfr, Sköfnungr, which is the best sword to have come to Iceland [...]."

60 E.I. Ward observes that the burials at Borre in Norway "show extensive evidence of postdepositional disturbance, although it is hard to tell how much of the original grave goods were removed" (E.I. WARD: Nested Narrative..., p. 43). See also B. MyrHE: Haugbrott eller gravplyndring $i$ tidlig kristningstid? In: Fra hammer til kros. 1000 år med kristendombrytningstid $i$ Viken. Eds. J.I. Hansen, K.G. BJerva, I. Lønning. Oslo 1994. 
to Iceland is both a nod at its name-recognition among medieval audience (not unlike the narrative remark about Tyrfingr) and an indication that other swords were similarly imported from abroad, bringing with them their own legends and "life-histories." Skeggi's new ownership of the ancient royal Sköfnungr might have contributed considerably to increasing his social stature upon his arrival to Iceland: the inhabitants of Miðfjörðr where he settled chose him as their goði. The sword's identity continuity was established and accepted in the eyes of his contemporaries, and whether or not it was indeed the genuine sword of Hrólfr kraki has no bearing on the narrative world of the sagas.

Sköfnungr shares a number of similarities with Tyrfingr, suggesting these properties were characteristic of fabled magic swords. As with Tyrfingr, it demands blood each time it is unsheathed: "Pat er náttúra sverðsins, at nökkurt verðr at höggva með pví, hvern tíma er brugðit er." ${ }^{\prime 61}$ Like Tyrfingr too, it brings victory in battle - as may be inferred by multiple occasions of saga characters seeking to borrow Sköfnungr for their fights, although its victorygranting property is never explicitly spelled out. ${ }^{62}$ Yet instead of treating this sword like an object, its wielders are compelled to bestow on it a reverence as if it were a person in its own right, such is the force of its tangible presence. This sword's "personality" is narrated in starkly animate terms as it reacts to the violence it unleashes: "sverðit Sköfnungr bítr, ok gnestr hann nú hátt í peira hausum; en nattúra Sköfnungs var sú, at hann kvað við hátt, pá hann kendi beinanna." ${ }^{63}$ Its ability to produce organic and vocal, even if inarticulate, sound imbues it with an additional degree of self-autonomy further removing it from being a mere inert thing; indeed, it may be possible to call this thing a being of its own. Here too one may recall Tyrfingr's sinister shining, as well as the singing of Gunnarr's famous halberd in Brennu-Njáls saga as it anticipates spilling blood. ${ }^{64}$ The eerie toll Sköfnungr exerts on bodies and minds of those who come in contact with it may be evidenced by conditional restrictions of its

${ }^{61}$ Pórðar saga hreðu..., ch. 12: "It is the nature of the sword that something must be struck with it, each time it is drawn." The attribute of taking a life on each draw is likewise shared by the sword Dáinsleif, wielded by king Högni in mythic battle of Hjaðningavíg. Dáinsleif is mentioned only in Snorri Sturluson's $13^{\text {th }}$-century Skáldskaparmál (SNORRI Sturluson: Edda. Skáldskaparmál I. Ed. A. FAulKes. London 1998, ch. 50, p. 72).

${ }^{62}$ Kormákr the skald seeks to borrow Sköfnungr in chapter 9 of Kormáks saga, and Pórkell Eyjólfsson asks the same in chapter 57 of Laxdcela saga.

${ }^{63}$ Hrólfs saga kraka..., ch. 50, p. 102: "the sword Sköfnungr bites, and now groans loudly in their skulls; such was the nature of Sköfnungr that it spoke loudly when it met the bone."

${ }^{64}$ Brennu-Njáls saga. Ed. Einar Ólafur Sveinsson. Íslenzk fornrit 12. Reykjavík 1954, ch. 30 , p. 80 . Though commonly translated as "ringing," the original Old Icelandic is unmistakeably imbuing this halberd with vocal sound: "pegar veit, er víg er vegið með atgeirinum, pví að svo syngur í honum áđur að langt heyrir till" "“it is known at once when a killing is to be made with the halberd, for [something] sings in it beforehand, that it may be heard a long way off"). Note again the curious use of passive voice to describe the halberd's singing, akin to Tyrfingr's eerie shining discussed in footnote 39 above. 
usage: "sú er náttúra sverðsins, at eigi skal sól skína á hjǫltin, ok honum skal eigi bregða, svá at konur sé hjá." ${ }^{65}$ Keeping a weapon out of sight is sensible regardless of its alleged magic, but coupled with Sköfnungr's killing urge these precautions attain a darker dimension. Inherent in these warnings is the danger and tension this object generates by its mere presence, as if threatening to erupt out of control any moment.

As with Heiðrekr's violent paroxysm when clutching Tyrfingr unsheathed, Pórðar saga hreðu gives a glimpse of Sköfnungr's influence upon its wielder. The following scene unfolds at a wedding feast to which Skeggi arrives in a bad mood, soured by the presence of the titular hero Póror with whom he has had unresolved quarrels. When Skeggi falls asleep at the table, the sword Sköfnungr is at his back. Pórðr, displeased with Skeggi's comportment, reaches towards Sköfnungr and unsheathes it. As narrative tension escalates, the saga continues:

[...] tók hann sverðið Sköfnung og brá. Eiðr mælti, "Petta er parfleysa fóstri minn." Pórðr svarar, "Hvað mun saka?” Eiðr segir, "Рað er náttúra sverðsins að nokkuð verður að höggva með pví hvern tíma er brugðið er.” Pórðr segir, "Рað skal prófa" og hljóp út og kvað hann skyldu görtra við merarbeinin og höggur hross eitt er stóð í túninu. Eiðr kvað petta illa orðið. Nú vaknar Skeggi og saknar bæði sverðsins og Pórðar. Hann varð reiðr og hljóp út og spurði hvort Pórðr hefði tekið sverðið. Eiðr segir, "Eg veld pví faðir minn er Pórðr hjó hrossið pví að eg sagði náttúru sverðsins." Pórðr kvaðst sjálfr valda. ${ }^{66}$

The sword's hunger is appeased through killing a horse, Skeggi's distemper is appeased through reconciliatory compensation that follows shortly after, and the crisis of unsheathing is averted to everyone's relief. But does Pórðr, Sköfnungr in hand, resourcefully maintain self-awareness as he runs out looking for a scapegoat, or is this running out itself an impulsive urge to slay whatever comes into his sight? There is a curious juggle of agency as characters discuss what happened, each trying to claim responsibility for the killing, which only serves to illustrate further ambiguity over who owns this act. Does hearing of Sköfnungr's properties inspire Pórðr's pre-emptive measures, or does Eiðr's

${ }^{65}$ Laxdcela saga..., ch. 57, p. 172: "such is the nature of the sword, that the sun should not shine on its hilt, and it should not be drawn when women see it."

${ }^{66}$ Pórðar saga hreðu..., ch. 12: "[...] he took the sword Sköfnungr and drew it. Eiður [Skeggi's son fostered by Pórðr] said, 'that is pointless, my foster-father.' Pórðr answered, 'on account of what?' Eiðr says, 'That is the nature of the sword that something must be hewn with it each time it is drawn.' Póror says, 'that is to be tried,' and ran outside and said he shall grind mare's bone, and struck a horse that stood in the hedge. Eiðr said it was ill done. Now Skeggi wakes and misses both the sword and Pórðr. He was angry and ran outside and asked if Pórðr had taken the sword. Eiðr says, 'I caused it, my father, that Pórðr struck the horse because I mentioned the sword's nature.' Pórðr said he himself caused it.” 
explanation only motivate him to take the blade for a reckless swing? Pórðr's attempt to reassert control betrays a need to do so, perhaps trying to restore his self-validation after letting it slip. Earlier in the saga, he is himself the intended target of Sköfnungr, escaping with his life when Skeggi, carrying the sword unsheathed in his hand, chooses to avert bórðr's death by venting the sword's bloodlust on another human being. "Launaði eg nú Sköfnungi pað að honum var brugðið," Skeggi declares after killing an innocent man, absolving himself of any remorse. ${ }^{67}$ As Pórðr stands over a dead animal and offers compensation for it, graver implications are hovering over the scene than chopping horse meat in trifle.

Is it the sword that kills, or is it the wielder? A close cognate may here be drawn with modern debates on gun control. It bears remembering that medieval audiences did not romanticise swords as modern readers tend to do: temporal distance and chivalric associations lend the swords a certain exoticism in nowadays perceptions. To saga contemporaries, however, bladed implements were the killing technology of their own times. The narrative unease generated by a character's unsheathing of a magic sword might be comparable to someone wielding a loaded automatic rifle. It is the coiled tension of its affordances that makes it so disturbingly compelling, simultaneously repulsive and attractive - acting on the body by letting it perform in ways not previously available, and acting on the mind by letting it loose. The fear and the danger is that of one's own lapse of inhibition, of being prone to erupt any given moment. The careful handling instructions and conditional use of Sköfnungr may be attributed to responsible attempts in keeping this weapon under control, and yet they ironically contribute to augmenting its agency: the more restrictions surrounding an object, the greater its perceived potency and the greater, perhaps, temptation to use it. Its fatal charisma and its pull recalibrate the personhood of its user, and both become mere parts of a new organism growing out of this contact in which the boundaries between the self and the object are transgressed, both playing an equal role in shaping this new composite entity.

\section{Concluding Remarks: Networks of Distributed Identities}

In an otherwise terse and reticent saga prose, keeping close focus on portrayals of objects has yielded nuanced insights into saga characters' psychological

\footnotetext{
${ }^{67}$ Dórðar saga hreðu..., ch. 10: "now I have repaid Sköfnungr for unsheathing it."
} 
states and the ways their personhood is constructed, deconstructed, and redistributed through their engagements with material artefacts. Upon considering the above depictions, their correspondence flows may be mapped twofold:

1) ecological axis (human - environment - contagion),

2) interpersonal axis (human — object personhood redistribution).

Extractions of crafted objects from their "native" contextual habitats and bringing them where they do not belong charges objects with tension from these disturbances, resulting in uneasy relations between them and their new users. Proximity and presence of such objects in users' personal micro-ecologies implicitly brings with it traces of these objects' past users, contextual circumstances, and temporal layers in these objects' life-histories, potentially extending all the way to the artisans who made them. This nested multiplicity of meanings, the knowledge of which an object's current user may or may not have access to, results in a composite and multi-authored entity imbued with personhood as it keeps on accruing ever new social layers throughout its existence. To what extent do swords' namings and personifications stem from attempts to familiarise - and thus exercise control over - these otherwise cacophonous multiplicities of inter-tangled agentive forces and identities?

Objects' life-histories not only infuse them with meanings, but broach the boundaries between myth and everyday. Any crafted object may thus become a receptacle of similar stories as it passes hands, and the unique individual features of each hand-crafted item further infuse it with character - personhood - of its own, for no two are exactly the same. Widely circulating tales of objects of supernatural origin spill into perceptions of everyday objects as potentially similarly imbued with powers of their own. The ordinary may easily become extraordinary, and it bears questioning to what extent the concept of mundane ordinary things is a post-medieval "objectification" fuelled by consumerist mentality conflating artisan craftsmanship with mass production, a notion utterly alien to medieval audience. ${ }^{68}$ As objects travel, so do the stories and narratives of their perceived potencies. Discrepancies in saga variants attest to the enigmatic charisma material artefacts exerted upon imaginations as different scribes attempted to interpret and articulate the swords' ambiguous agencies in their own ways. Instead of depicting persons as discrete entities, they let them narratively emerge as continuously unfolding, shaping each other and being shaped by each other. Dynamic plasticity of these networks sheds light on the role of objects in renegotiating human boundaries - not only cultural or geographical, but boundaries of human minds and bodies, of what constituted self and personhood across the medieval North.

${ }^{68}$ Martin Heidegger raises this issue in his phenomenological reassessment of encountering everyday items; see M. HeIDEgGer: Being and Time. Transl. by J. Macquarrie, E. Robinson. Oxford 1962, division 15, p. 98. 
It is crucial to underscore there was not "one" pan-Norse mode of personhood and self-experience, and it becomes more accurate instead to speak of the viking age as having composite identities, always in process of renegotiation and recalibration according to affordances granted by context and circumstance. While Fowler's ideas of dividual personhood, both permeability and partibility, are eminently fitting for medieval Norse contexts, the present enquiry's aim was not to "find" them in saga texts but rather to open the sagas up for further studies in material engagement by demonstrating validity and applicability of conceptual frameworks which challenge Cartesian paradigms. It becomes clear that Old Norse identity concepts were far more fluid and slippery than our modern terminology allows for, calling for new theoretical apparata that account for the multiplicities, discrepancies, and idiosyncrasies that do not fit monolithic structural frameworks.

\section{References}

\section{Primary sources}

Brennu-Njáls saga. Ed. EINAR ÓLAFUR Sveinsson. Íslenzk fornrit 12. Reykjavík 1954.

Gísla saga súrssonar. In: Vestfirðinga sögur. Eds. BJöRn K. Pórólfsson, GUĐNI Jónsson. Íslenzk fornrit 6. Reykjavík 1943.

Grettis saga. Ed. GuĐNi Jónsson. Íslenzk fornrit. Reykjavík 1936.

Hauksbók, udg. efter de Arnamagnaeanske håndskrifter no. 371, 544 og 675, 4, samt forskellige papirshåndskrifter af det Kongelige nordiske oldskrift-selskab. Eds. EIRÍKUR Jónsson, FInNuR Jónsson. København 1892-1896.

Hervarar saga ok Heiðreks konungs. Ed. JóN Helgason. København 1924.

Hervarar saga ok Heiðreks. Eds. G. Turville-Petre, C. Tolkien. London 1956.

Hrólfs saga kraka. In: Fornaldar sögur Nordrlanda eptir Gömlum Handritum. Vol. 1. Ed. C.C. RAFN. Kaupmannahöfn 1829.

The Kalevala. The Epic Poem of Finland. Transl. by J.M. Crawford. New York 1888.

Kormáks saga. In: Vatnsdcela saga. Ed. Einar Ólafur Sveinsson. Íslenzk fornrit 8. Reykjavík 1939.

Kumlbúa páttr. In: Harðar saga. Eds. ĐóRHALluR Vilmundarson, BJARNi Vilhjálmsson. Íslenzk fornrit 13. Reykjavík 1991.

Landnámabók. Ed. ЈАков Benediktsson. Íslenzk fornrit 1. Reykjavík 1986.

Laxdoela saga. Ed. EinAR Ólafur Sveinsson. Íslenzk fornrit 5. Reykjavík 1934.

MoOrCock M.: Elric of Melniboné. London 1972.

The Saga of King Heidrek the Wise. Saga Heidreks konungs ins Vitra. Ed. and transl. by C. TOLKIEN. London 1960. 
SNORri Sturluson: Edda. Skáldskaparmál I. Ed. A. Faulkes. London 1998.

Tolkien J.R.R.: The Fellowship of the Ring. Part I of The Lord of the Rings. New York 1965.

TOLKIEN J.R.R.: The Silmarillion. London 1977.

pórðar saga hreðu. In: Kjalnesinga saga. Ed. JóHANnes Halldórsson. Íslenzk fornrit 14. Reykjavík 1959.

\section{Secondary sources}

Appadurai A.: The Social Life of Things: Commodities in Cultural Perspective. Cambridge 1988.

Barresi J., Martin R.: History as Prologue: Western Theories of the Self. In: The Oxford Handbook of the Self. Ed. S. Gallagher. Oxford 2013.

Belk R.W.: Possessions and the Extended Self. "Journal of Consumer Research" 1988, Vol. 15.

Bennett J.: Vibrant Matter. A Political Ecology of Things. Durham-London 2010.

BRYNJA Porgeirsdóttir: Humoral Theory in the Medieval North: An Old Norse Translation of Epistula Vindiciani in Hauksbók. "Gripla" 2018, Vol. 29.

Clark A., Chalmers D.J.: Extended Mind. "Analysis" 1998, Vol. 58, No. 1.

Clover C.J.: Maiden Warriors and Other Sons. "The Journal of English and Germanic Philology" 1986, Vol. 85, No. 1.

DuczKo W.: Obecność skandynawska na Pomorzu i stowiańska w Skandynawii we wczesnym średniowieczu. In: Salsa Cholbergiensis. Kołobrzeg w średniowieczu. Eds. L. LeCIEJEWICZ, M. RęBKowsKi. Kołobrzeg 2000.

Duczko W.: Scandinavians in the Southern Baltic between the $5^{\text {th }}$ and the $10^{\text {th }}$ Centuries AD. In: Origins of Central Europe. Ed. P. UrbańCZYK. Warszawa 1997.

Duczko W.: Viking-Age Wolin (Wollin) in the Norse Context of the Southern Coast of the Baltic Sea. "Scripta Islandica" 2014, Vol. 65.

Duczko W.: Viking Rus. Studies on the Presence of Scandinavians in Eastern Europe. Leiden-Boston 2004.

Fell C.E.: The First Publication of Old Norse Literature in England and Its Relation to Its Sources. In: The Waking of Angantyr: The Scandinavian Past in European Culture. Eds. E. Roesdahl, P.M. Sørensen. Aarhus 1996 (Acta Jutlandica Vol. LXXI, No. 1. Humanities Series 70).

Fowlen C.: The Archaeology of Personhood: An Anthropological Approach. London-New York 2014.

INGOLD T.: Rethinking the Animate, Re-animating Thought. "Ethnos: Journal of Anthropology" 2006, Vol. 71, No. 1.

Hedenstierna-Jonson C.: Borre Style Metalwork in the Material Culture of the Birka Warriors: An Apotropaic Symbol. "Fornvännen: Journal of Swedish Antiquarian Research" 2006, Vol. 101, No. 5.

Heidegger M.: Being and Time. Transl. by J. Macquarrie, E. Robinson. Oxford 1962.

Hildburgh W.L.: Psychology Underlying the Employment of Amulets in Europe. "Folklore" 1950-1951, Vols 51-52.

Gallagher S.: How the Body Shapes the Mind. Oxford 2006.

Gardela L., Odebäck K.: Miniature Shields in the Viking Age: A Reassessment. "Viking and Medieval Scandinavia” 2018, Vol. 14. 
Gardela L.: Scandinavian Amulets in Viking Age Poland. "Collectio Archaeologica Ressoviensis" 2014, Vol. 33.

Gardela L.: Vikings in Poland. A Critical Overview. In: Viking Worlds: Things, Spaces and Movement. Eds. M.H. Eriksen, U. Pedersen, B. Rundberget, I. Axelsen, H. Berg. Oxford 2015.

Gell A.: Art and Agency: An Anthropological Theory. Oxford 1998.

Gospen C.: What Do Objects Want? "Journal of Archaeological Method and Theory" 2005, Vol. 12, No. 3.

Kanerva K.: Porous Bodies, Porous Minds. Emotions and the Supernatural in Íslendingasögur (ca. 1200-1400). "Annales Universitatis Turkuensis" 2015, Vol. 398.

KRISTJÁN Eldjárn: Kuml og haugfé: úr heiðnum sið á Íslandi. Reykjavík 1953.

Kristú́n Eldjárn, Adolf Friðriksson: Kuml og Haugfé. $2^{\text {nd }}$ edition. Reykjavík 2000.

LAYHer W.: Caught Between Worlds: Gendering the Maiden Warrior in Old Norse. In: Women and Medieval Epic: Gender, Genre, and the Limits of Epic Masculinity. Eds. S.S. Poor, J.K. Schulman. New York 1997.

Lindow J.: Pórsteinn páttr skelks and the Versimilitude of Supernatural Experience in Saga Literature. In: Structure and Meaning in Old Norse Literature: New Approaches to Textual Analysis and Literary Criticism. Eds. J. Lindow, L. LönnRoth, G.W. Weber. Odense 1986.

Malafouris L.: How Things Shape the Mind: A Theory of Material Engagement. Cambridge, Massachusetts 2013.

Malafouris L.: Is It "Me" or Is It "Mine"? The Mycenaean Sword as a Body-part. In: Past Bodies: Body Centered Research in Archaeology. Eds. J. RobB, D. Boric. Oxford 2008.

Mauss M.: The Gift: The Form and Reason for Exchange in Archaic Societies. Transl. by W.D. Halls with a foreword by M. Douglas. New York 1990 (Original publ. 1925).

Mayburd M.: Between a Rock and a Soft Place: Materiality of Old Norse Dwarves and Paranormal Ecologies in fornaldarsögur. In: Supernatural Encounters in Old Norse Literature and Tradition. Eds. D. SAvborg, K. Bek-Pedersen. Turnhout 2018.

Mayburd M.: "Helzt póttumk nú heima i millim..." A Reassessment of Hervör in Light of seiðr's Supernatural Gender Dynamics. "Arkiv för nordisk filologi” 2014, Vol. 129.

Mayburd M.: Kumlbúa páttr and the Paranormal Event. The Traumatic Ontology of Being in Time in Medieval Iceland. In: From Rus' to rimur: New Norse Studies. Ed. S.F.D. Hughes et al. Occasional issue, "New Norse Studies." Ithaca, New York (forthcoming).

Mayburd M.: The Hills Have Eyes: Post-Mortem Mountain Dwelling and the (Super)natural Landscapes in Íslendingasðgur. "Viking and Medieval Scandinavia" 2014, Vol. 10.

Mayburd M.: The Paranormal. In: The Routledge Research Companion to the Medieval Icelandic Sagas. Eds. Ármann Jakobsson, SverRIR Jakobsson. New York 2017.

Morawiec J.: Vikings among the Slavs. Jomsborg and the Jomsvikings in Old Norse Tradition. "Studia Medievalia Septentrionalia" 2009, Vol. 17.

Morawiec J.: Wolin w średniowiecznej tradycji skandynawskiej. Kraków 2010.

Motz L.: The Wise One of the Mountain: Form, Function, and Significance of the Subterranean Smith. A Study in Folklore. Göppingen 1983 (Göppinger Arbeiten zur Germanistik).

Myrhe B.: Haugbrott eller gravplyndring i tidlig kristningstid? In: Fra hammer til kros. 1000 år med kristendombrytningstid $i$ Viken. Eds. J.I. Hansen, K.G. BJeRVA, I. LønNing. Oslo 1994.

Nemeroff C.J., Rozin P.: The Contagion Concept in Adult Thinking in the United States: Transmission of Germs and of Interpersonal Influence. "Ethos: Journal of the Society for Psychological Anthropology" 1994, Vol. 22. 
Newman G.E., Bartels D.M., Smith R.K.: Are Artworks More Like People Than Artifacts? Individual Concepts and Their Extensions. "Topics in Cognitive Science" 2014, Vol. 6, No. 4.

Newman G.E., Diesendruck G., Bloom P.: Celebrity Contagion and the Value of Objects. "Journal of Consumer Research" 2011, Vol. 38.

OrRI Vésteinsson: The Archaeology of Landnám. Early Settlement in Iceland. In: Vikings: The North Atlantic Saga. Eds. W.F. Fitzhugh, E.I. WARD. Washington 2000.

Price N.: The Viking Way. Magic and Mind in Late Iron Age. Oxford 2019.

Rовв J.E.: The Extended Artefact and the Monumental Economy. In: Rethinking Materiality: The Engagement of Mind with the Material World. Eds. E. DeMarrais, C. Gosden, C. Renfrew. Cambridge 2005.

Rozin P., Nemeroff C.J., Wane M., Sherrod A.: Operation of the Sympathetic Magical Law of Contagion in Interpersonal Attitudes among Americans. "Bulletin of the Psychonomic Society" 1989, Vol. 27.

SAYERS W.: Sexual Identity, Cultural Integrity, Verbal and Other Magic in Episodes from Laxdoela saga and Kórmaks saga. "Arkiv för nordisk filologi" 1992, Vol. 107.

Semple S.: Perceptions of the Prehistoric in Anglo-Saxon England: Religion, Ritual, and Rulership in the Landscape. Oxford 2012.

Shilling C.: The Body in Culture, Technology and Society. London 2004.

Social Norms in Medieval Scandinavia. Eds. J. Morawiec, A. Jochymek, G. Bartusik. Leeds 2019.

StanisŁawski B., Filipowiak W.: Wolin wczesnośredniowieczny. Część I. Warszawa 2013 (Origines Polonorum, Vol. 6).

StARk L.: The Charmer's Body and Behaviour as a Window onto Early Modern Selfhood. In: Charms, Charmers, and Charming: International Research on Verbal Magic. Ed. J. RoPER. Hampshire-New York 2009.

Stark L.: The Magical Self: Body, Society, and the Supernatural in Early Modern Rural Finland. Helsinki 2006 (Folklore Fellows' Communication, Vol. 290).

Szajnocha K.: Lechicki poczatek Polski. Lwów 1858.

The Cognitive Life of Things: Recasting the Boundaries of the Mind. Eds. L. Malafouris, R. RenfRew. Cambridge 2010.

The Oxford Handbook of the Self. Ed. S. Gallagher. Oxford 2013.

Wachowski K.: Jomsborg. Normannowie wobec Polski w X w. Studyum historyczne. Warszawa 1914 (Prace Towarzystwa Naukowego Warszawskiego, Vol. 2).

Ward E.I.: Nested Narrative: Pórðar saga hreðu and Material Engagement. PhD thesis, University of California, Berkeley 2012, https:/escholarship.org/uc/item/1g10j16f [accessed: $7^{\text {th }}$ August 2020].

WÄrmländer S.K.T.S., Zori D., Byock J., Scott D.A.: Metallurgical Findings from a Viking Age Chieftain's Farm in Iceland. "Journal of Archaeological Science” 2010, Vol. 37.

DóRA Pétursdóttir: "Deyr fé, deyja frcendr": Re-animating Mortuary Remains from Viking Age Iceland. MA thesis, University of Tromsø 2007, https://hdl.handle.net/10037/1165 [accessed: $7^{\text {th }}$ August 2020]. 


\section{Miriam Mayburd}

\section{Przedmioty i sprawczość na Północy w okresie średniowiecza - przypadek staronordyckich magicznych mieczy}

Streszczenie

Literackie opisy magicznych mieczy w sagach staronordyckich podkreślają aktywną rolę przedmiotów w kształtowaniu i renegocjowaniu kulturowych konstruktów osobowości i tożsamości. Poprzez skupienie uwagi na narracyjnych obrazach tych artefaktów oraz psychosomatycznej dynamice interakcji bohaterów sagi z nimi niniejsze opracowanie naświetla ekologiczne powiązania pomiędzy przestrzenią poznawczą i materialną na Północy w okresie średniowiecza, podkreślając międzykulturową zmienność i zróżnicowanie, typowe dla średniowiecznych wizji świata.

Słowa klucze: ontologia zorientowana na przedmiot, sprawczość materialna, archeologia kognitywna, osobowość i tożsamość, sagi staronordyckie

\section{Miriam Mayburd}

\section{Objekte und Wirkung im Norden im Mittelalter - der Fall der altnordischen Zauberschwerter}

Zusammenfassung

Literarische Beschreibungen von magischen Schwertern in den altnordischen Sagen betonen die aktive Rolle von Objekten bei der Gestaltung und Neuverhandlung kultureller Konstrukte von Persönlichkeit und Identität. Da die narrativen Bilder dieser Artefakte und die psychosomatische Dynamik der Interaktion der Sagenhelden mit ihnen im Fokus dieser Studie stehen, werden die ökologischen Verbindungen zwischen dem kognitiven und materiellen Raum im Norden in der Zeit des Mittelalters beleuchtet, wobei die für mittelalterliche Weltanschauungen typische interkulturelle Variabilität und Vielfalt herausgestellt werden.

Schlüsselwörter: objektorientierte Ontologie, materielle Wirkung, kognitive Archäologie, Persönlichkeit und Identität, altnordische Sagen 